\title{
COOPERATION OF UNIVERSITIES WITH BUSINESS IN POLAND AND THE USA - PERSPECTIVE OF SCIENTIFIC ENVIRONMENT
}

\author{
Agnieszka CZERWIŃSKA-LUBSZCZYK \\ University of Bielsko-Biala \\ Michalene GREBSKI \\ Northampton Community College, Monroe Campus \\ Dominika JAGODA-SOBALAK \\ Opole University of Technology
}

\begin{abstract}
:
University and business cooperation offers many benefits not only for the parties involved. It translates into innovation and competitiveness of the economy. The relationship encounters many barriers that are related to the environment (both internal and external) in which it is implemented. The aim of the article is to identify the determinants of university-business cooperation (areas of cooperation, barriers, motivations) and to point out recommendations from the perspective of scientists in Poland and the United States (USA). The experience of USA researchers can be used as a background for considerations about cooperation between universities and business in Poland, and as an example of good practices for the purpose of supporting and improving the analyzed relationships. The article focuses on selected determinants of university and business cooperation: areas of cooperation, barriers limiting it, motivations for cooperation and the possible options for its improvement (recommendations of researchers). In order to achieve the assumed goals, an individual, in-depth interview was conducted with the use of a questionnaire as the research tool. The presented results of the research showed significant differences between the models of university and business cooperation in Poland and the USA.
\end{abstract}

Key words: university-business cooperation, determinants of cooperation, researchers, universities cooperation

\section{INTRODUCTION}

Cooperation between universities and business brings many tangible benefits for each party. For universities, it is primarily an opportunity to obtain funding for research and to verify the theoretical assumptions in real conditions, or an opportunity for the development of practical skills for both university employees and students. Business is a kind of "testing ground" for the university. It is an opportunity to implement patents for new technical and technological solutions or to improve the employability rates of graduates. For entrepreneurs [11] it primarily involves the joint development and implementation of new products, processes, technologies, and an opportunity to attract apprentices and trainees, and then qualified employees. Cooperation between the sphere of science and businesses is a synergy of knowledge and experience.

The issue of cooperation between universities and business is often addressed in the literature [10, 26, 33, 36], and empirical research often focuses on cooperation undertaken for the purpose of commercializing research $[14,17,19,29]$. The specific nature of the environment (legal conditions, cultural and social factors, systemic solutions regarding financing and implementation of scientific and research works [4]) may mean, that solutions developed in other countries, or recommendations directed to enterprises or universities operating in different conditions cannot be transferred directly.

Given the specifics of the problem under study, and especially legal changes that have occurred recently in Poland, it seems that despite numerous studies in the field of university-business cooperation, it is worth continuing scientific research in this field.

The aim of the article is to identify the determinants of university-business cooperation (areas of cooperation, barriers, motivations) and to point out recommendations from the perspective of scientists in Poland and the USA. 
According to The Global Competitiveness Report 2018 published by The World Economic Forum, assessing the competitiveness of economies, the USA is a pioneer in the field of stakeholder cooperation for innovation [31]. In the overall assessment, the USA ranks first, while Poland ranks 37. Economic competitiveness indicators are grouped into twelve pillars, one of which is "R\&D Innovation". In 2017, this indicator included "University-industry collaboration in R\&D". The USA came in second (after Switzerland) in this indicator, while Poland came in at 89 [30]. The experience of USA researchers can be used as a background for considerations about cooperation between universities and business in Poland, and as an example of good practices for the purpose of supporting and improving the analyzed relationships.

\section{THEORETICAL BACKGROUND}

\section{University-business cooperation}

The issue of cooperation between universities and business is often addressed by researchers. There are studies on entities surrounding this relationship $[2,3,12,17,22$, 35]. In an analysis of the existing literature on the subject Epure [6] draws attention to publications devoted to: innovation accelerators, technology transfer offices, high technology centers, business incubators, science parks, spin-offs (sponsored or unsponsored). The authors focus on the individual aspects of this relationship, e.g. the role of mentoring during student internships [25]. The role of government in shaping relations is often emphasized, including on the basis of the triple-helix partnerships and the quadruple helix partnership models [22, $29,32,34$. The research is conducted using quantitative $[3,20]$, as well as qualitative methods [3, 19, 20, 23, 29]. University-business cooperation could be defined as "a model of inter-institutional arrangement between organizations of a fundamentally distinct nature, which may have different purposes and adopt huge different formats" [34]. Kesting, Gerstlberger and Baaken [14] noticed that university-business cooperation means that it "is in fact the individual researcher who cooperates with businesses and decides for or against engagement".

\section{Area of cooperation}

The authors of research in the field of university-business cooperation focus on one area of cooperation or include a number of different areas. Due to the specificity of the entities involved, it is also worth paying attention to such aspects as: the education process (including the innovation in teaching) and the graduates' integration on the labor market [6]. Liu, Li and McLean [18] focus on educating students. D'Este and Patel [16] emphasize the importance of staff exchange, conducting joint research, creating joint patents and publications, licensing, opening spin-offs, laboratories. Informal contacts related to meetings or participation in conferences are also important. D. Gill et al. [15] focus on relationships that are based on relationships between people, e.g. delegating lecturers to industry or inviting industrial specialists to university laboratories. In their research conducted among Polish enterprises Fajfer, Koliński and Kolińska [7] analyzed a number of areas of cooperation. Cooperation in the field of training turned out to be the most common type of cooperation. Cooperation in the field of projects was also very important.

\section{Motivation to cooperation}

Ranga, Perälampi, and Kansikas [28] analyzed the development of university-business cooperation in Finland based on a case study conducted in four universities. The authors focused on university-level education (e.g. decline of overall government funding for university research, caused by budget cuts; diffusion of innovation; training students about professional environment; providing employment). It turned out, that individual universities focus on different motivators.

According to the report [21] from a project implemented by the Ministry of Regional Development in Poland, based on surveys among 27 research centers, the acquisition of new funds was of the greatest importance for the studied researchers. Other common motivations included increasing the prestige of the research center, gaining access to practical knowledge in the application of research results, and improving the flow of information between the scientific society and business.

Jakubiak and Chrapowicki [12] studied university-business cooperation in implementing innovative products in Poland. They focused on the commercialization of research results. The authors listed factors facilitating the establishment and implementation of cooperation, i.a. the conviction of both parties that cooperation is worthwhile because it can bring about benefits.

\section{Barriers of cooperation}

Universities' cooperation with business encounters many barriers that are related to the environment (both internal and external) in which it is implemented. Liu, Li and McLean [18] point to the fact, that "some cooperation is only a formality and signs an agreement, but no substantive progress".

Galán-Muros and Plewa [9] conducted research in 33 countries of the European Economic Area and listed a wide range of barriers: connection barriers (e.g. difficulty in finding the appropriate cooperation partner), funding barriers (e.g. lack of university funding), organizational culture barriers (e.g. differing motivation/values between university and business). It has been shown that barriers have a diverse effect on cooperation with business, even though the influence remains negative for all barriers, except for the lack of funding.

Based on a study conducted in the Czech Republic, Kadlec and Blažek [13] indicated barriers to technology transfer. Gajewska and Kurowska-Pysz [8] listed a catalog of barriers hindering the process of knowledge transfer from universities to enterprises in Poland. Barriers existing on the part of the universities include focus on teaching and basic research; lack of a properly marketed offer of services; low price competitiveness of the offer; shortage of accredited laboratories for research and development services; bureaucracy and high formalization of procedures extending the duration of services. The 
Orłowski report on the commercialization of scientific research in Poland [24] shows that the most important barriers identified on the part of the universities include the low level of inventors' material interest in commercialization, the lack of experience and skills of cooperation with business, or the lack of clear rules for settling costs and revenues from commercialization in scientific institutions.

\section{METHODOLOGY}

The aim of the article is to identify the determinants of university-business cooperation (areas of cooperation, barriers, motivations) and to point out recommendations from the perspective of scientists in Poland and the United States.

The following research objectives were formulated:

1. Identification of the areas of university-business cooperation in Poland and the USA.

2. Identification of the barriers limiting university-business cooperation in Poland and the USA.

3. Identifying motivators for university-business cooperation in Poland and the USA.

4. Indication of the scientists' recommendations in the field of university-business cooperation.

The following thesis has been formulated for the indicated research objectives: there are differences between the model of university-business cooperation in Poland and the USA.

In order to achieve the assumed goals, an individual, indepth interview was conducted with the use of a questionnaire as the research tool.

The interview questionnaire was developed on the basis of literature analysis and the tools for researching university-business cooperation included in the publications. Some of the questions were taken from the publications - the questions were used in unchanged form or were adapted for the needs of the questionnaire. For the purpose of the final verification of the questionnaire, pilot studies were carried out, as a result of which the section devoted to the respondents' particulars was changed and the introduction to the study was expanded.

The following criteria for selecting respondents were taken into account:

- diversity criterion: 3 Polish and 3 American universities, universities of various profiles (technical and humanities) and size (according to the number of students), employees representing each level of the scientific career (assistant lecturers, adjunct professors, professors);

- effectiveness criterion - the scientist's knowledge about the university's cooperation with business (persons indicated by other employees of a given university as cooperating with business and having experience in this field that allows them to provide reliable information in this regard)

- accessibility criterion: willingness of the researcher to give an interview and physical possibility (time and place).
Interviews with researchers were carried out in the first quarter of 2019.

\section{RESULTS}

Eighteen university employees ( 9 from Poland, 9 from the USA) took part in the interviews. They represented a total of 6 universities ( 3 from Poland, 3 from the USA) and three scientific career levels (in Poland: assistant lecturer (3 persons), adjunct professor (3), professor (3); in the USA: associate professor/full professor (4), assistant professor (3), instructor (2).

All the surveyed persons declared practical experience in business. However, there are differences in the nature of this cooperation. In the USA, all researchers emphasized practical experience in scientific and research work as well as design work. Polish researchers included in the study mainly pointed to short-term (ad hoc) forms of cooperation such as apprenticeships, internships and civillaw contracts. Only one person was employed pursuant to an employment contract and one person reported conducting their own business activity.

In the United States, workers frequently move between business and academia. Universities attract good engineers from business, and business attracts good engineers from universities. Consequently, knowledge and experience are exchanged and creativity is stimulated to solve unconventional engineering problems. In the interviews carried out in Poland, there was no mention of such transfers between the two domains.

The total period of professional experience in business is also different. As many as 6 out of 9 of the studied researchers in the USA declared cooperation with business lasting over 5 years, while only 2 of the persons surveyed in Poland reported similar length of experience in this regard.

The studied researchers focused on different areas of cooperation (Tab. 1).

Table 1

Areas of cooperation in Poland and USA

\begin{tabular}{|c|c|c|}
\hline Items of areas of cooperation & $\begin{array}{l}\text { PL } \\
\text { No. }\end{array}$ & $\begin{array}{l}\text { USA } \\
\text { No. }\end{array}$ \\
\hline $\begin{array}{l}\text { Consultations of entrepreneurs with re- } \\
\text { searchers }\end{array}$ & 8 & 9 \\
\hline Courses and training & 7 & 9 \\
\hline $\begin{array}{l}\text { Preparation of opinions, expert opinions for } \\
\text { entrepreneurs }\end{array}$ & 4 & 9 \\
\hline Research and development work & 4 & 9 \\
\hline $\begin{array}{l}\text { Internships/apprenticeships for stu- } \\
\text { dents/graduates }\end{array}$ & 4 & 9 \\
\hline $\begin{array}{l}\text { Participation in conferences and informal } \\
\text { meetings with enterprises }\end{array}$ & 4 & 9 \\
\hline $\begin{array}{l}\text { Staff exchange, secondment of research } \\
\text { workers }\end{array}$ & 2 & 9 \\
\hline
\end{tabular}

Among the studied Polish researchers, the most frequently mentioned areas of cooperation were consultations of entrepreneurs with researchers and courses/training. Other areas mentioned by researchers:

- teaching trips -2 persons, 
- development of new training programs for students -2 persons,

- assistance in the preparation of production documentation -1 person.

In the USA consultations between entrepreneurs and researchers, courses and training, preparation of opinions and expert opinions for entrepreneurs, internships/apprenticeships for students/graduates, participation in conferences and informal meetings with enterprises, or the exchange of staff and the secondment of researchers were mentioned as obvious areas of cooperation. The surveyed researchers focused on experience gained in developing and testing a new product based on the invention, in particular:

- development of a new product based on an invention -9 persons,

- testing and evaluation of a new product - 9 persons,

- working with start-up companies in a business incubator center as a part of an "entrepreneurial teambuilding project" -6 persons,

- development of a new technology -6 persons,

- rapid prototyping and testing -6 persons,

- implementation of continuous quality improvement process (CQI) -6 persons,

- basic research -3 persons.

Cooperation barriers were evaluated by scientists on a 5-point scale, where 1 means definitely disagree, 2-rather disagree, 3-no opinion, 4-rather agree, and 5 means definitely agree with the given statement. The wording took the form: "I see the following barriers to university and business cooperation in Poland (USA) ...". Results attached in Table 2. Dominant was used.

Table 2

Barriers of cooperation in Poland and USA

\begin{tabular}{|c|c|c|}
\hline Items of barriers of cooperation & $\begin{array}{l}\mathrm{PL} \\
\mathrm{D}\end{array}$ & $\begin{array}{l}\text { USA } \\
\text { D }\end{array}$ \\
\hline Research workers' focus on teaching activities & 5 & 3 \\
\hline $\begin{array}{l}\text { Excessive burden of organizational activity on } \\
\text { the research workers }\end{array}$ & 5 & 3 \\
\hline $\begin{array}{l}\text { Bureaucracy and high formalization of proce- } \\
\text { dures extending the time required } \\
\text { for the implementation of services }\end{array}$ & 5 & 4 \\
\hline $\begin{array}{l}\text { Shortage of accredited laboratories for the } \\
\text { purposes of research and development ser- } \\
\text { vices }\end{array}$ & 5 & 4 \\
\hline Lack of access to funds for research & 4 & 3 \\
\hline $\begin{array}{l}\text { Lack of a properly marketed offer for the } \\
\text { companies }\end{array}$ & 4 & 3 \\
\hline $\begin{array}{l}\text { Low price competitiveness of the universities' } \\
\text { offer }\end{array}$ & 4 & 5 \\
\hline $\begin{array}{l}\text { Too much concentration on basic scientific re- } \\
\text { search }\end{array}$ & 3 & 3 \\
\hline $\begin{array}{l}\text { Lack of knowledge about the opportunities of } \\
\text { working with different organizations e.g. busi- } \\
\text { ness incubators, spin-off/spin-out companies, } \\
\text { innovation and technology transfer centers }\end{array}$ & 3 & 3 \\
\hline $\begin{array}{l}\text { Improper criteria for performance assess- } \\
\text { ment of faculty }\end{array}$ & 2 & 3 \\
\hline $\begin{array}{l}\text { Lack of faculty experience in conducting uni- } \\
\text { versity and industry projects }\end{array}$ & 2 & 3 \\
\hline
\end{tabular}

The studied Polish researchers (Tab. 2) pointed out the following barriers to cooperation: research workers' focus on teaching activities, excessive burden of organizational activity on the research workers, bureaucracy and high formalization of procedures extending the time required for the implementation of services, shortage of accredited laboratories for the purposes of research and development services.

The respondents also mentioned the following barriers:

- lack of time allocated for conducting research and for contact with a scientist at the enterprises,

- lack of recognition at the university level of the practical work carried out in enterprises as part of scientific and didactic activities (lack of points or low scores awarded for such cooperation, or extreme requirements for their recognition in the employee assessment),

- low flexibility of work at the university.

American respondents saw the barriers as less severe the dominant values were in most cases: 3 . The main barriers are: high-cost factor of industry and university projects - lack of competitiveness, shortage of accredited laboratories for the purposes of research and development services and bureaucracy and high formalization of procedures extending the time required for the implementation of the services.

In addition, USA respondents pointed out, that:

- the involvement of students in performing a capstone design project for the industry requires coordination of those projects with the university calendar,

- cost factor of university/industry projects is sometimes higher than the cost of hiring a private engineering consulting firm,

- establishing a working relationship between the university faculty and industry requires a lot of initiative on the part of the faculty,

- cooperation with industry helps with promotion and tenure, but it does not bring extra compensation.

The survey also examined factors motivating researchers to take up cooperation with business. They were evaluated by researchers on a 5-point scale, where 1 means definitely disagree, 2- rather disagree, 3- no opinion, 4- rather agree, and 5 means definitely agree with the given statement. The wording took the form: "My cooperation with enterprises is motivated by: ...".

Results attached in Table 3. Dominant was used. In addition, Polish researchers mentioned:

- timeliness and relevance of research topics - new trends, technical and organizational innovations,

- direct contact with business - learning about economic realities.

Researchers from the United States (Tab. 3) rated the listed motivators highly (dominant: 5 ), except for two: the possibility of obtaining additional remuneration and the possibility of reducing the teaching hours. 
Table 3

Motivation to cooperation in Poland and USA

\begin{tabular}{llc}
\hline \multicolumn{1}{l}{ Items of motivation to cooperation } & PL & USA \\
\hline $\begin{array}{l}\text { The possibility of obtaining additional remu- } \\
\text { neration }\end{array}$ & 5 & 1 \\
$\begin{array}{l}\text { Prestige } \\
\text { Access to practical knowledge }\end{array}$ & 5 & 5 \\
The possibility of publishing research results & 5 & 5 \\
$\begin{array}{l}\text { Exchange of experiences between myself and } \\
\text { the company's employees }\end{array}$ & 5 & 5 \\
$\begin{array}{l}\text { Verification of the usefulness of scientific re- } \\
\text { search }\end{array}$ & 5 & 5 \\
$\begin{array}{l}\text { The possibility of practical training of students } \\
\text { A way to reduce my teaching load }\end{array}$ & 5 & 5 \\
$\begin{array}{l}\text { An increased chance to receive a promotion at } \\
\text { the university }\end{array}$ & 1 & 3 \\
$\begin{array}{l}\text { Pressure or encouragement from the univer- } \\
\text { sity authorities }\end{array}$ & 1 & 5 \\
\hline
\end{tabular}

Interestingly, the possibility of additional earnings was very highly rated by respondents in Poland, and the opportunity to reduce teaching hours was not mentioned at all.

This does not mean that researchers in the USA do not receive additional remuneration related to research activities, e.g. when selling a patent the university retains $50 \%$ of the value and the other $50 \%$ is paid to the employee who is the author of the given solution. In addition, in the USA, the National Science Foundation and other research funding agencies reimburse the employee's earnings, in full or in part, to the university, which allows for a reduction of teaching hours. With this money, the university employs another person to conduct classes, and the researcher conducting research at that time does not conduct classes with students at all or has a reduced number of teaching hours.

Motivators related to the possibility of obtaining promotion at the university or the pressure from the university authorities appeared only in the responses of USA respondents (dominant: 5) and were not prominent at the Polish research units (dominant: 1 ).

The surveyed researchers also see various possibilities for strengthening the universities' cooperation with the business community. The question: "Please briefly describe what should be improved in the legal, financial and organizational sphere of cooperation between universities and business?" - had an open form. In the research institutes in the USA, suggestions for developing business-science cooperation focus on solving the problem of civil liability, lowering didactic hours in exchange for cooperation with enterprises, improving cooperation through a common internet platform on which the demand for research and research offers could be announced. The surveyed Polish researchers particularly focus on reducing the high university overhead, bureaucracy, improving the flow of information and the decision-making process, simplifying commercialization and developing a system for offering research and reporting cooperation needs.

\section{DISCUSSION AND CONCLUSIONS}

Literature analysis has shown that the problem of cooperation between universities and business is addressed relatively frequently by researchers, however, the empirical research often focuses on cooperation undertaken for the purpose of commercialization of research. Rampersad [27] also draws attention to this issue.

According to a study commissioned by the Polish Ministry of Science and Higher Education, based on interviews with employees of scientific centers, as many as $99 \%$ of researchers declare willingness to search for entrepreneurs interested in cooperation [1]. Despite such a high percentage of affirmative responses among Polish researchers, university-business cooperation is not at the same level as in the USA, for example, as indicated by reports assessing the competitiveness of economies [5, $30,31]$. There are many reasons and limitations of cooperation between universities and business in Poland, just as there are many motivators to undertake it. The article is an attempt to present the differences in the models of university-business cooperation in Poland and the USA. The article focuses on selected determinants of university and business cooperation: areas of cooperation, barriers limiting it, motivations for cooperation and the possible options for its improvement (recommendations of researchers). The presented results of the conducted research showed significant differences between the models of university and business cooperation in Poland and the USA.

Research shows that university-business cooperation is viewed differently by researchers in Poland and the USA. In the USA, all surveyed employees are practically obligated by universities to engage in cooperation with business. However, due to the number of cooperation programs, developed models, such as the lowering of didactic hours, culture of cooperation, this activity is seen by them as a natural element of their career.

Studies have shown that USA respondents saw the cooperation barriers as less severe. Differences were also noticed in terms of motivations. Polish researchers (according to studies) are motivated to cooperate, among other things, by the possibility of additional earnings, which was not emphasized by USA employees. However, a comparison of the earnings at universities in Poland and in the USA could help in better understanding these differences.

The limitations of the conducted study were the result of factors such as the selection of the research sample. Due to the small sample size we should exercise caution when formulating conclusions about university and business cooperation. A more comprehensive comparison between research results in Poland and the USA would require larger sample sizes.

When trying to make international comparisons, it is necessary to pay attention to the differences in the environment in which the cooperation between universities and business occurs, e.g. the political, economic, social, technological, ecological factors [4]. Due to the size 
of the article, these issues were not included in the analysis. However, it would seem necessary to address them in the case of comprehensive research in this field.

The next step in the study of university-business cooperation will be to show this relationship from the perspective of enterprises.

\section{REFERENCES}

[1] Bariery współpracy przedsiębiorców i ośrodków naukowych. Ministerstwo Nauki i Szkolnictwa Wyższego. Departament Wdrożeń i Innowacji, 2006.

[2] K. Caban-Piaskowska, A. Miarka, M. Mielczarek. „The Artist - University - Company: Creating Business Relationships Network." Handel Wewnętrzny, vol. 5(376), pp. 2533, 2018.

[3] S.M. de Conto and A.A. Feil. "The need for inter-organizational relationships vis-a-vis the current market structure." Navus-Revista de Gestao e Tecnologia, vol.7(3), pp. 34-45, 2017.

[4] A. Czerwińska-Lubszczyk, M. Grebski, D. Jagoda-Sobalak. „Współpraca uczelni z przemysłem - finansowanie i realizacja prac naukowo-badawczych w Polsce i w USA." Systemy Wspomagania w Inżynierii Produkcji, Górnictwo perspektywy, zagrożenia, vol. 8(1), pp. 35-50, 2019.

[5] S. Dutta, B. Lanvin, S. Wunsch-Vincent. Global Innovation Index 2018. Energizing the World with Innovation. Geneva: World Intellectual Property Organization, 2018.

[6] M. Epure. "University-business cooperation: adapting the curriculum and educational package to labor market requirements," Proc. of the International Conference on Business Excellence, 2017, Vol. 11(1), pp. 339-349.

[7] P. Fajfer, A. Koliński, K. Kolińska. „Analiza możliwości transferu wiedzy oraz współpracy praktyki gospodarczej ze środowiskiem naukowym - wyniki badań." E-mentor, vol. 2 (49), pp. 55-60, 2013.

[8] P. Gajewska and J. Kurowska-Pysz. „Relacje nauka - biznes: wybrane czynniki kształtujące współpracę uczelni wyższych i przedsiębiorstw". Logistyka, vol. 5, pp. 56-62, 2012.

[9] V. Galán-Muros and C. Plewa. "What drives and inhibits university-business cooperation in Europe? A comprehensive assessement." R\&D Management, vol. 46(2), pp. 369-382, 2016.

[10] T.D.H. Gusberti, M.F. Dewes. "Impact evaluation for University-Business Cooperation and Technology Transfer in higher education systems: cluster analysis." Production, vol. 27, pp. 1-15, 2017.

[11] D. Jagoda-Sobalak, I. Lapunka, K. Marek-Kolodziej. „The Importance of Creativity, Motivation and Communication in the Business World," Proc. of the Conference: $31^{\text {st }}$ International-Business-Information-Management-Association, 2018, pp. 1229-1239.

[12] M. Jakubiak and P. Chrapowicki. „Wdrażanie Nowych Produktów Innowacyjnych jako Efekt Współpracy Szkół Wyższych z Przedsiębiorcami." Zeszyty Naukowe Politechniki Ślqskiej, Organizacja i Zarzq̨dzanie, z. 114, 2017, pp. 167-177.

[13] V. Kadlec and J. Blažek. "University-Business Collaboration as Perceived by Leading Academics: Comparising And Contrasting The Two Most Innovative Czech Regions." Erdkunde, vol. 69(4), pp. 327-339, 2015.

[14] T. Kesting, W.D. Gerstlberger, T. Baaken. "A benefit segmentation approach for innovation-oriented universitybusiness collaboration." International Journal of Technology Management, vol. 76(1-2), pp. 58-80, 2018.
[15] A. Kuna-Marszałek. "Budowa Powiązań Nauki z Biznesem - Przegląd Badań." Prace Naukowe Uniwersytetu Ekonomicznego we Wrocławiu, vol. 315, pp. 439-449, 2013, [za:] D. Gill, T. Minshall, C. Pickering, M. Rigbyet. Funding Technology: Britain Forty Years on. Cambridge: University of Cambridge Institute for Manufacturing, $2007 \mathrm{pp}$. 50.

[16] A. Kuna-Marszałek. "Budowa Powiązań Nauki z Biznesem - Przegląd Badań." Prace Naukowe Uniwersytetu Ekonomicznego we Wrocławiu, vol. 315, pp. 439-449, 2013, [za:] P. D'Este, P. Patel. „University-industry linkages in the UK: What are the factors underlying the variety of interactions with industry?," Research Policy, vol. 36, pp. 1295-1313, 2007.

[17] P. Lavarell, M. Minervini, V. Robert. "From collaboration networks for innovation to the development of science and technology clusters. Two case studies at the National University of San Martin in Argentina." Revista Brasileira De Inovaca, vol. 16(2), pp. 299-324, 2017.

[18] Y.N. Liu, K. Li, A. McLean. "Practical Scientific Knowledge Education based on Herbert Spencer's "What Knowledge is of Most Worth?." Eurasia Journal of Mathematics Science and Technology Education, vol. 13(7), pp. 42914299, 2017.

[19] V.M. Mikosz and I.A. de Lima. "The university-enterprisegovernment relationship in the context of the brazilian National System of Science, Technology and Innovation: a case study of cooperation mechanisms and their intervening aspects in a Public University." Revista Tecnologia e Sociedade, vol. 14 (34), pp. 215-239, 2018.

[20] F.B. Mussi. "Characterization of Interinstitutional Cooperation in Parana State: An Analysis from the Universities Perspective." Administracao-Ensino E Pesquisa, vol. 17(2), pp. 327-354, 2016.

[21] Najlepsze praktyki w zakresie współpracy ośrodków naukowych i biznesu przy wykorzystaniu środków z UE. Warszawa: Fundacja Aurea Mediocritas, 2008.

[22] D. Nemova, R. Bagautdinov, A. Mushinskiy. "UniversityBusiness Cooperation Based on Virtual Research Information Service." International Scientific Conference Urban Civil Engineering and Municipal Facilities, vol. 117, pp. 1115-1121, 2015.

[23] M.C. Ojeda, C.G. Gonzalez, H.O. Zelada. "The Role of Proximity in the University-Industry-Government Cooperation: The Case of the Agri-Food Industry in the Region of Coquimbo, Chile." Revista Universidad Empresa, vol. 21(36), pp. 61-78, 2019.

[24] W.M. Orłowski. Komercjalizacja badań naukowych w Polsce. Bariery i możliwości ich przełamani. Warszawa: PwC, 2013.

[25] S. Osipova, N. Kuzmina, N. Gafurova, V. Osipov. „Mentoring as a Form of Assistance to a Transport University Student in the "University-Enterprise" Networking Cooperation." Tem Journal-Technology Education Management Informatics, vol. 8(1), pp. 234-241, 2019.

[26] L. Raesfeld and P.G. Fuentes. "University-Business Cooperation in the Regional Innovation System in the State of Hidalgo." Revista Conrado, vol. 14(65), pp. 240-246, 2018.

[27] G.C. Rampersad. "Developing university-business cooperation through work-integrated learning". International Journal of Technology Management, vol. 68 (3-4), pp. 203-227, 2015.

[28] M. Ranga, J. Perälampi, J. Kansikas. „The new face of university-business cooperation in Finland," Science and Public Policy, vol.43(5), pp. 601-612, 2016. 
[29] S.X. Riberio, M.S. Nagano. "Elements influencing knowledge management in university-business-government collaboration: Case studies in National Institutes of Science and Technology." Knowledge and process Management. The Journal of Corporate Transformation, vol 23(3), pp. 207-219, 2018.

[30] K. Schwab. The Global Competitiveness Report 20172018. Geneva: The World Economic Forum, 2017.

[31] K. Schwab. The Global Competitiveness Report 2018. Geneva: The World Economic Forum, 2018.

[32] T. Suslova, E. Pokrovskaya, M. Raitina. "Transdisciplinary Cooperation Within Realization of Idea of "Triple Helix", Proc. of the International Conference Responsible Research and Innovation, 2017, vol. 26, pp. 809-814.

[33] M.A. Suzdalova, V.G. Lizunkov, R.Y. Malushko, N.A. Sytina, V.E. Medvedev. "Innovative Forms of Partnership in Development and Implementation of University-Business Cooperation," Proc. of the III International Scientific Symposium on Lifelong Wellbeing in The World, 2017, vol. 19 , pp. 450-455.

\section{Agnieszka Czerwińska-Lubszczyk \\ ORCID ID: 0000-0001-8100-8802 \\ University of Bielsko-Biala, \\ Faculty of Management and Transport, \\ Department of Economic and Social Science \\ ul. Willowa 2, 43-309 Bielsko-Biała, Poland \\ e-mail: aczerwinska@ath.bielsko.pl}

\section{Michalene Grebski}

ORCID ID: 0000-0002-3487-4473

Northampton Community College, Monroe Campus

2411 PA-715 Tannersville, PA 18372, USA

e-mail: mgrebski@northampton.edu

\section{Dominika Jagoda-Sobalak}

ORCID ID: 0000-0003-3085-6603

Opole University of Technology,

Faculty of Production Engineering and Logistics,

Department of Management and Production Engineering

ul. Ozimska 75, 45-370 Opole, Poland

e-mail: d.jagoda@po.opole.pl
[34] C.T.S. Tatum, F.F.D. Franceschi, L.M.M. Tatum, J.P. Fabris, S.L. Russo. "University-Industry Cooperation Network in Academic and Technological Productivity." Revista Geintec-Gestao Inovacao e Tecnologias, vol. 8(4), pp. 4697-4709, 2018.

[35] R. Wolniak, M.E. Grebski, B. Skotnicka-Zasadzien. "Comparative Analysis of the Level of Satisfaction with the Services Received at the Business Incubators (Hazleton, PA, USA and Gliwice, Poland)." Sustainability, vol. 11(10), pp. 1-22, 2019.

[36] V. Zuzeviciute, B. Praneviciene, Z. Simanaviciene, V. Vasiliauskiene. "Competence for Sustainability: Prevention of Dis-Balance in Higher Education: The Case of Cooperation While Educating Future Law Enforcement Officers." Montenegrin Journal of Economics, vol. 13(4), pp. 121130, 2017. 